\title{
KONTRIBUSI PAJAK RESTORAN TERHADAP PENDAPATAN ASLI DAERAH
} KOTA BITUNG

\author{
Christian Ferdinand Majampoh ${ }^{1}$, Inggriani Elim² ${ }^{2}$ I Gede Suwetja ${ }^{3}$ \\ ${ }^{1,2,3}$ Jurusan Akuntansi, Fakultas Ekonomi dan Bisnis, Universitas Sam Ratulangi, Jl. Kampus Bahu, Manado, \\ 95115, Indonesia
}

Email : majampohenand@gmail.com

\begin{abstract}
Law no. 32 of 2004 on Local Government to determine local taxes one source of revenue coming from the region. For that we need to examine how big the contribution of restaurant tax to PAD Bitung City. Local taxes are divided into two parts: provincial tax and city / county tax. One type of city / district tax is Restaurant Tax. This study aims to determine the contribution of restaurant tax Bitung City. Research method used in this research is descriptive analysis method. The object of research is taken at the Office of Regional Tax and Retribution Board of Bitung City. This study shows the calculation by using the contribution analysis can be seen that the contribution of restaurant tax Bitung city in the period 2013 2017 decreased. The rate of growth of restaurant tax in the early period had experienced a growth in restaurant tax revenues despite the last year (2017) there was a very significant decrease so that the value is negative. This study shows that Bitung City Government has not been able to reach the target that has been determined, this is because not yet maximum supervision from the Office of Revenue Management Finance and Regional Assets Bitung City in levy restaurant tax, so there are still many restaurants that do not pay taxes. The conclusion obtained is the analysis of restaurant tax contribution in the City of Bitung in the year 2013 amounted to $2.41 \%$ and there was a decrease in 2017 to become $1.09 \%$. For that Bitung City Local Government should be more firm and pro active again in levy restaurant tax.
\end{abstract}

Keywords: Restaurant Tax, PAD

\section{PENDAHULUAN}

Indonesia sudah lama telah melakukan pembangunan yang dikenal istilah pembangunan nasional. Pembangunan merupakan suatu aktifitas kegiatan yang dilakukan dalam rangka mengadakan perubahan atau pengembangan ke arah keadaaan yang lebih baik dari tahun ketahun yang sifatnya memperbaiki dan bertujuan untuk meningkatkan kesejahteraan masyarakat dan memajukan pertumbuhan ekonomi. Pemerintah harus berusaha mengoptimalkan sumber pendapatan agar pembangunan bisa berhasil. Pembanguna bisa berhasil jika ada sumber penerimaan yang kuat, dimana sumber pembiayaan diusahakan tetap bertumpu pada penerimaan dalam negeri maupun penerimaan dari sumber-sumber luar negeri yang hanya sebagai pelengkap.

Pendapatan Asli Daerah (PAD) merupakan semua penerimaan daerah yang berasal dari sumber pendapatan daerah yang secara bebas dapat dikelolah oleh masing-masing daerah untuk dan membiayai semua urusan daerah dalam konteks pembangunan daerah. Untuk mengurangi ketergantungan kepada pemerintah pusat, pemerintah daerah perlu berusaha meningkatkan Pendapatan Asli Daerah yang salah satunya dengan mengoptimalkan potensi sumber pendapatan daerah di Pemerintah Kota Bitung Provinsi Sulawesi Utara dalam meningkatkan kemampuan di bidang pendanaan untuk pembangunan. Untuk itu pemerintah harus mengoptimalkan penerimaan pajak restoran, supaya penerimaan pemerintah bisa meningkat sehingga akan memperlancar pembangunan. Untuk mencapai kemajuan 
pembangunan, pemerintah harus melakukan perbaikan dalam mekanisme pemungutan dan pengawas pemungutan sehingga semua pendapatan daerah dapat dimaksimalkan. Sesuai dengan latar belakang, maka permasalahan dalam penelitian ini adalah bagaimana kontribusi pajak restoran terhadap Pendapatan Asli Daerah Pemerintah Kota Bitung serta pentingnya kontribusi pajak restoran dan laju pertumbuhan pajak restoran terhadap PAD di Kota Bitung karena sumber pendapatan dari pajak restoran akan berguna untuk membiayai semua urusan dalam konteks pembangunan di Pemerintah Daerah Kota Bitung.

\section{TINJAUAN PUSTAKA}

Definisi Pajak. Menurut Soemitro, R yang dikutip oleh Mardiasmo ( $2016: 1$ ) pajak secara umum adalah suatu iuran wajib dari penduduk atau masyarakat yang dibayarkan kepada negara yang mana iuran tersebut berdasarkan undang-undang yang berlaku, pemungutannya atau pelaksanaannya dapat dipaksakan, pihak yang membayar tidak mendapat imbalan secara langsung, serta hasilnya digunakan untuk pembangunan nasional.

Fungsi Pajak. Menurut Supramono dan Damayanti, T.W dalam bukunya yang berjudul "Perpajakan Indonesia" (2015), pajak memiliki dua fungsi, yaitu: (1) Fungsi Penerimaan (Budgetair); dan (2) Fungsi Mengatur (Regular).

Syarat Pemungutan Pajak. Supramono dan Damayanti, T.W dalam bukunya yang berjudul "Perpajakan Indonesia" (2015). Ada empat syarat dalam pemungutan pajak, yaitu :

1. Syarat keadilan.

2. Syarat yuridis.

3. Syarat ekonomis.

4. Syarat finansial.

Pendapatan Asli Daerah. PAD adalah semua hasil atau jumlah yang diterima/diperoleh pemerintah daerah baik yang berupa uang tunai atau nilai uang/material lainnya dalam satu tahun anggaran guna untuk membiayai pembangunan dan jalannya pemerintahan daerah dihitung satu tahun anggaran yang bersangkutan.

Pajak Restoran. Pajak Restoran adalah Pajak yang dikenakan langsung atas pelayanan yang disediakan restoran. Jumlah pembayaran yang diterima atau yang seharusnya diterima Restoran yang menjadi dasar pengenaan pajak restoran. Tarif pajak restoran ditetapkan $10 \%$.

Laju Pertumbuhan Ekonomi. Suryana, 2016 : 5 Pertumbuhan ekonomi adalah kenaikan GDP ( Gross Domestic Product) tanpa memandang bahwa kenaikan itu lebih besar atau lebih kecil dari pertumbuhan penduduk dan tanpa memandang apakah ada perubahan dalam struktur ekonominya.

\section{METODE PENELITIAN}

Jenis Penelitian. Teknik analisis data adalah proses penyederhanaan data ke dalam bentuk yang lebih mudah dibaca dan diinterprestasikan. Penulis menggunakan metode analisis deskriptif kualitatif yaitu mendeskripsikan data-data yang diperoleh dilapangan, kemudian data-data tersebut dianalisa mengenai sampai sejauh mana penerimaan Pajak Restoran yang mampu memberikan kontribusi pada Pemerintah Kota Bitung.

Tempat dan Waktu Penelitian. Penelitian ini dilakukan di Kantor Badan Pengelola Pajak Dan Retribusi Daerah Kota Bitung. Penelitian dilakukan pada bulan April 2018 sampai selesai.

Prosedur Penelitian. Langkah-langkah yang dilakukan dalam penelitian ini sebagai berikut:

1. Mengumpulkan teori-teori

2. Memilih teknik analisa data yang dilakukan

3. Mencari data yang digunakan

4. Menganalisa data yang didapat

5. Memberikan kesimpulan dan saran 
Objek Penelitian. Objek penelitian ini adalah penerimaan pungutan Pajak Restoran yang memberikan kontribusi terhadap Pendapatan Asli Daerah (PAD) Pemerintah Kota Bitung.

Metode Pengumpulan Data. Sumber data yang dikumpulkan dalam penelitian ini adalah data primer yang berasal dari objek penelitian yang dikumpulkan dengan cara berikut :

1. Wawancara, merupakan diskusi atau tanya jawab secara langsung terhadap objek penelitian.

2. Observasi, dengan mengadakan pengamatan secara langsung terhadap objek yang diteliti dan mencatat hal-hal yang diperlukan.

Metode Analisis. Penulis menggunakan metode analisis deskriptif kualitatif yaitu mendeskripsikan data-data yang diperoleh dilapangan, kemudian data-data tersebut dianalisa mengenai sampai sejauh mana penerimaan pungutan pajak restoran yang memberikan kontribusi terhadap Pendapatan Asli Daerah (PAD) Pemerintah Kota Bitung. Langkah-langka yang dilakukan dalam menganalis data adalah sebagai berikut.

1. Analisis yang digunakan untuk mengetahui seberapa besar kontribusi penerimaan pajak daerah terhadap PAD di Pemerintah Kota Bitung dalam kurun waktu 2015 - 2009 dan dapat dihitung dari realisasi penerimaan pajak restoran dibandingkan dengan jumlah PAD. Rumus yang digunakan untuk menghitung kontribusi sebagai berikut :

$$
\text { Kontribusi }=\frac{\text { Realisasi Pajak Restoran }}{\text { Pendapatan Asli Daerah }} \times 100 \%
$$

2. Untuk menghitung laju pertumbuhan pajak restoran terhadap PAD di Kota Bitung dalam kurun waktu 2013 - 2017 maka digunakan rumus sebagai berikut.

$$
\text { Growth }=\frac{X_{1}-X_{0}}{X_{0}} \times 100 \%
$$

Keterangan :

$\begin{array}{ll}\text { Growth } & =\text { Pertumbuhan Pajak Restoran } \\ \mathrm{X}_{1} & =\text { Tahun Sekarang } \\ \mathrm{X}_{0} & =\text { Tahun Sebelumnya }\end{array}$

\section{HASIL PENELITIAN DAN PEMBAHASAN}

\subsection{Hasil Penelitian}

Data Penelitian. Dari hasil penelitian yang didapat penulis memperoleh data dari Kantor Badan Pengelola Pajak dan Retribusi Daerah Pemerintah Kota Bitung yang dituangkan pada Tabel 1 :

Tabel 1. Target Pajak Restoran, Realisasi Pajak Restoran dan Realisasi PAD tahun 2013-2017

\begin{tabular}{crrr}
\hline $\begin{array}{c}\text { Tahun } \\
\text { Anggaran }\end{array}$ & $\begin{array}{c}\text { Target Pajak } \\
\text { Restoran (Rupiah) }\end{array}$ & $\begin{array}{c}\text { Realisasi Pajak } \\
\text { Restoran (Rupiah) }\end{array}$ & $\begin{array}{c}\text { Realisasi Pendapatan Asli } \\
\text { Daerah (Rupiah) }\end{array}$ \\
\hline 2013 & 43.200 .000 & 80.276 .440 & 3.329 .113 .141 \\
2014 & 52.500 .000 & 90.374 .523 & 5.509 .268 .855 \\
2015 & 64.696 .250 & 109.684 .574 & 6.216 .529 .180 \\
2016 & 93.132 .208 & 165.645 .119 & 9.685 .115 .330 \\
2017 & 123.132 .208 & 125.102 .795 & 11.509 .980 .985 \\
\hline
\end{tabular}

Sumber: Badan Pengelola Pajak dan Retribusi Daerah Pemerintah Kota Bitung 
Tabel 1 diatas merupakan data target pajak restoran, realisasi pajak restoran dan realisasi Pendapatan Asli Daerah tahun 2013 - 2017, yang berhubungan dengan permasalahan yang sedang diteliti. Dari hasi yang didapat menunjukkan penerimaan pajak restoran sangat baik bahkan melebihi target yang direncanakan oleh pemerintah Pemerintah Kota Bitung.

Analisis Kontribusi. Kontribusi pajak restoran Kota Bitung dihitung dengan membandingkan jumlah penerimaan pajak restoran dengan jumlah penerimaan pendapatan asli daerah. Kontribusi yaitu membandingkan jumlah realisasi pajak restoran dan dibagi dengan pendapatan asli daerah kemudian pajak restoran terhadap PAD di pemerintahan Kota Bitung disajikan pada Tabel 2 berikut ini :

Tabel 2. Kontribusi Pajak Restoran Terhadap Pendapatan Asli Daerah Pemerintah Kota Bitung tahun 2013-2017

\begin{tabular}{crcc}
\hline $\begin{array}{c}\text { Tahun } \\
\text { Anggaran }\end{array}$ & $\begin{array}{c}\text { Realisasi Pajak } \\
\text { Restoran (Rupiah) }\end{array}$ & $\begin{array}{c}\text { Pendapatan Asli Daerah } \\
\text { (Rupiah) }\end{array}$ & $\begin{array}{c}\text { Kontribusi Pajak } \\
\text { Restoran (\%) }\end{array}$ \\
\hline 2013 & 80.276 .440 & 3.329 .113 .141 & 2,41 \\
2014 & 90.374 .523 & 5.509 .268 .855 & 1,64 \\
2015 & 109.684 .574 & 6.216 .529 .180 & 1,76 \\
2016 & 165.645 .119 & 9.685 .115 .330 & 1,71 \\
2017 & 125.102 .795 & 11.509 .980 .985 & 1,09 \\
\hline
\end{tabular}

Sumber: Badan Pengelola Pajak dan Retribusi Daerah Pemerintah Kota Bitung.

$$
\text { Tahun } 2013=\frac{80.276 .440}{3.329 .113 .141} \times 100 \%=2,41 \%
$$

Pada tahun 2013 kontribusi Pajak Restoran terhadap Pendapatan Asli Daerah Pemerintah sebesar $2,41 \%$.

$$
\text { Tahun } 2014=\frac{90.374 .523}{5 \cdot 509.268 .855} \times 100 \%=1,64 \%
$$

Pada tahun 2014 kontribusi Pajak Restoran terhadap Pendapatan Asli Daerah Pemerintah sebesar $1,64 \%$.

$$
\text { Tahun } 2015=\frac{109.684 .574}{6.216 .529 .180} \times 100 \%=1,76 \%
$$

Pada tahun 2015 kontribusi Pajak Restoran terhadap Pendapatan Asli Daerah Pemerintah sebesar $1,76 \%$.

$$
\text { Tahun } 2016=\frac{165.645 .119}{9.685 .115 .330} \times 100 \%=1,71 \%
$$

Pada tahun 2016 kontribusi Pajak Restoran terhadap Pendapatan Asli Daerah Pemerintah sebesar $1,71 \%$.

$$
\text { Tahun } 2016=\frac{125.102 .795}{11.509 .980 .985} \times 100 \%=1,09 \%
$$

Pada tahun 2017 kontribusi Pajak Restoran terhadap Pendapatan Asli Daerah Pemerintah sebesar 1,09\%. 
Analisis Laju Pertumbuhan Pajak Restoran (Growth). Laju pertumbuhan Pajak Restoran dihitung dengan menggunakan rumus laju pertumbuhan yaitu, membandingkan selisih/perubahan penerimaan Pajak Restoran setiap Tahun Anggaran, dibagi dengan penerimaan pajak tahun sebelumnya dan dikali $100 \%$. Tingkat pertumbuhan penerimaan Pajak Restoran di Pemerintah Kota Bitung disajikan pada Tabel 3 berikut ini:

Tabel 3. Laju Pertumbuhan Pajak Restoran Pemerintah Kota Bitung Tahun 2013-2017

\begin{tabular}{ccc}
\hline Tahun Anggaran & Realisasi (Rupiah) & Pertumbuhan (\%) \\
\hline 2013 & 80.276 .440 & - \\
2014 & 90.374 .523 & $12,57 \%$ \\
2015 & 109.684 .574 & $21,37 \%$ \\
2016 & 165.645 .119 & $51,01 \%$ \\
2017 & 125.102 .795 & $-24,47 \%$ \\
\hline
\end{tabular}

Sumber: Badan Pengelola Pajak dan Retribusi Daerah Pemerintah Kota Bitung

$$
\text { Tahun } 2014=\frac{90.374 .523-80.276 .440}{80.276 .440} \times 100 \%=12,57 \%
$$

Tingkat pertumbuhan penerimaan Pajak Restoran Pemerintah Kota Bitung pada tahun 2014 sebesar $12,57 \%$.

$$
\text { Tahun } 2015=\frac{109.684 .574-90.374 .523}{90.374 .523} \times 100 \%=21,37 \%
$$

Tingkat pertumbuhan penerimaan Pajak Restoran Pemerintah Kota Bitung pada tahun 2015 sebesar $21,37 \%$.

$$
\text { Tahun } 2016=\frac{165.645 .119-109.684 .574}{109.684 .574} \times 100 \%=51,01 \%
$$

Tingkat pertumbuhan penerimaan Pajak Restoran Pemerintah Kota Bitung pada tahun 2016 sebesar $51,01 \%$.

$$
\text { Tahun } 2017=\frac{125.102 .795-165.645 .119}{165.645 .119} \times 100 \%=-24,47 \%
$$

Tingkat pertumbuhan penerimaan Pajak Restoran Pemerintah Kota Bitung pada tahun 2017 sebesar $-24,47 \%$.

\subsection{Pembahasan}

Analisis Kontribusi Pajak Restoran Terhadap Pendapatan Asli Daerah Pemerintah Kota Bitung. PAD merupakan salah satu sumber pendapatan daerah yang cukup diandalkan dan digunakan dalam menjalankan penyelenggaraan pemerintah dan pembangunan daerah. PAD tersebut dipungut berdasarkan peraturan daerah yang sesuai dengan peraturan perundang-undangan yang berlaku di Indonesia. Dari hasi yang didapat kontribusi pajak restoran terhadap Pendapatan Asli Daerah Pemerintah Kota Bitung terbesar adalah tahun 2013 sebesar 2,41\% dan terendah pada tahun 2017 sebesar 1,09\%. Naik turunnya kontribusi pajak restoran dikarenakan banyak tidaknya kunjungan kerestoran. 
Dengan adanya tingkat kontribusi yang bervariasi atau naik turun, Pemerintah Daerah Kota Bitung melakukan upaya mengoptimalkan sumber penerimaan asli daerahnya, yang salah satunya adalah penerimaan Pajak Restoran. Semua itu bisa terlaksana dengan adanya bantuan serta perhatian dari seluruh masyarakat. Dari hasil yang didapat tingkat persentase kinerja keuangan disajikan pada Tabel 4 berikut ini :

Tabel 4. Kontribusi Pajak Restoran Terhadap Pendapatan Asli Daerah Pemerintah Kota Bitung

\begin{tabular}{ccc}
\hline Tahun Anggaran & $\begin{array}{c}\text { Persentase Kinerja } \\
\text { Keuangan }\end{array}$ & $\begin{array}{c}\text { Kriteria Kinerja } \\
\text { Keuangan }\end{array}$ \\
\hline 2013 & $2,41 \%$ & Sangat Kurang \\
2014 & $1,64 \%$ & Sangat Kurang \\
2015 & $1,76 \%$ & Sangat Kurang \\
2016 & $1,71 \%$ & Sangat Kurang \\
2017 & $1,09 \%$ & Sangat Kurang \\
\hline
\end{tabular}

Sumber : Data olahan, 2018

Tahun 2013-2017 mempunyai persentase kinerja keuangan rata-rata sebesar 1,72\% tergolong dalam kriteria sangat kurang. Kriteria sangat kurang berarti bahwa Pajak Restoran harus ditingkatkan lagi dan perlu diperhatikan dengan baik agar supaya semua urusan dalam konteks pembangunan bisa di biayai.

Analisis Laju Pertumbuhan Pajak Restoran Pemerintah Kota Bitung. Dari hasil yang didapat sangat jelas menggambarkan kemampuan dari pemerintah Pemerintah Kota Bitung untuk mempertahankan dan juga meningkatkan keberhasilan dalam memungut Pajak Restoran dari tahun ketahun. Mardiasmo ( 2015 : 63 ) mengemukakan bahwa pertumbuhan Pajak Daerah masih lemah disebabkan karena banyak pendapatan Pajak Daerah yang tidak dioptimalkan oleh karena itu, Pemerinta Daerah harus berpupaya mengoptimalkan semua potensi penerimaan terlebih khusus pajak restoran kemudian dicatat dalam sistem yang ada, serta harus diteliti apakah masyarakat sudah membayar pajak dan buat para petugas apakah sudah berkerja dengan benar yang ada dilapangan. Pada tahun 2013 tidak ada karena tahun 2013 merupakan tahun yang pertama dalam penelitian ini. Selanjutnya tahun 2014 pertumbuhan penerimaan pajak restoran terhadap PAD di Pemerintah Kota Bitung sebesar 12,57\%. Selanjutnya tahun 2015 mengalami peningkatan menjadi sebesar $21,37 \%$. Selanjutnya juga terjadi peningkatan ditahun 2016 menjadi sebesar 51,01\%, ini merupakan persentase pertumbuhan terbesar dari kurun waktu 2013 - 2017. Namun ditahun berikutnya yakni tahun 2017 merupakan tahun penelitian terakhir terjadi penurunan sehingga bernilai negatif sebesar $-24,47 \%$. Berdasarkan analisis perhitungan yang sudah disajikan dalam penelitian ini memberikan hasil bahwa secara nominal perkembangan penerimaan Pajak Restoran di pemerintah daerah Kota Bitung dari tahun 2013 sampai dengan tahun 2017 mengalami perkembangan yang sangat signifikan yaitu pada tahun 2016 dari tahun sebelumnya. Meskipun ditahun 2017 terjadi penurunan sehingga bernilai negatif. Hasil perhitungan persentase pertumbuhan Pajak Restoran pada Tabel 3 kemudian dibandingkan dengan kriteria penilaian Tabel 5 berikut ini : 
Tabel 5. Pertumbuhan Pajak Restoran Pemerintah Kota Bitung tahun 2013-2017

\begin{tabular}{ccc}
\hline Tahun Anggaran & $\begin{array}{c}\text { Persentase Laju } \\
\text { Pertumbuhan }\end{array}$ & Kriteria \\
\hline 2013 & - & - \\
2014 & $12,67 \%$ & Tidak berhasil \\
2015 & $21,37 \%$ & Tidak berhasil \\
2016 & $51,01 \%$ & Kurang Berhasil \\
2017 & $-24,47 \%$ & Tidak berhasil \\
\hline
\end{tabular}

Sumber : Data olahan, 2018

Berdasarkan analisis yang didapat pada Tabel 5 diatas, secara nominal penerimaan Pajak Restoran di Pemerintah Daerah Kota Bitung dari tahun 2013 sampai dengan 2016 mengalami perkembangan yang baik. Tapi terjadi satu kali penurunan pada tahun 2017, namun laju pertumbuhan Pajak Restoran di Pemerintah Kota Bitung tetap mempunyai persentase yang positif tiap tahunnya. Pajak Restoran di Pemerintah Daerah Kota Bitung dipengaruhi besar kecilnya sumber penerimaan tiap tahunnya dan mempengaruhi naik turunnya laju pertumbuhan pajak restoran di Pemerintah Daerah Kota Bitung. Pada tahun 2014 laju pertumbuhan Pajak Rstoran sebesar 12,57\%, tahun 2015 naik menjadi 21,37\%, terjadi peningkatan yang sangat potensial pada tahun 2016 menjadi 51,01\%. Kemudian tahun 2017 mengalami penurunan sehingga menjadi $-24,47 \%$.

Dalam jangka waktu 5 (lima) tahun anggaran, penerimaan Pajak Restoran Pemerintah Kota Bitung terus mendapat persentase positif dari tahun ketahun, dimana berturut-turut tahun 2014, 2015, 2016 persentase pertumbuhannya sebesar 12,57\%, 21,37\%, 51,01\%. Tahun 2016 menunjukan persentase pertumbuhan terbesar, yakni sebesar 51,01\%. Walaupun persentase pertumbuhan tiap tahunnya tergolong postif, namun semuanya masih tergolong dalam kriteria tidak berhasil dan kurang berhasil. Dikatakan tidak berhasil karena persentase pertumbuhan tiap tahunnya sangat rendah atau tidak signifikan (dibawah 30\% dan tidak mencapai 55\%). Hasil penelitian yang dilakukan oleh penulis menunjukan bahwah dengan adanya kontribusi pajak restoran terhadap Pendapatan Asli Daerah berperan penting untuk menunjang pembangunan daerah, hal ini sejalan dengan penelitian yang dilakukan sebelumnya oleh Edward (2013), Alfan (2015), Randy (2013) pada Dinas Pendapatan Daerah Kota Manado, Kabupaten Minahasa Utara dan Kabupaten Minahasa.

\section{KESIMPULAN DAN SARAN}

\subsection{Kesimpulan}

Berdasarkan hasil penelitian dan pembahasan mengenai analisis kontribusi dan analisis laju pertumbuhan pajak restoran Badan Pengelola Pajak dan Retribusi Daerah Pemerintah Kota Bitung maka dapat diambil kesimpulan sebagai berikut :

1. Dari perhitungan dengan menggunakan analisis kontribusi dapat diketahui bahwa kontribusi pajak restoran Pemerintah Kota Bitung dalam kurun waktu 2013 - 2017 mengalami penurunan. Hal ini dikarenakan jumlah penerimaan PAD lebih besar dari pada penerimaaan Realisasi Pajak Restoran.

2. Berdasarkan hasil perhitungan, pertumbuhan pajak restoran Pemerintah Kota Bitung dalam kurun waktu 2013 - 2017 mengalami perkembangan penerimaan pajak restoran yang sangat signifikan meskipun ditahun berikut terjadi penurunan.

\subsection{Saran}

Berdasarkan hasil yang didapat, saran yang bisa diajukan kepada Pemerintah Daerah Kota Bitung yaitu sebagai berikut : 
1. Pemerintah Daerah Kota Bitung harus mengoptimalkan sumber penerimaan pajak restoran terhadap Pendapatan Asli Daerah (PAD) karena terjadi penurunan, sehingga diharapkan pemerintah dapat terus meningkatkan penerimaan pajak restoran.

2. Laju pertumbuhan untuk pajak restoran dari tahun 2013 - 2017 sangat baik karena terjadi peningkatan meskipun ditahun penelitian terakhir terjadi penurunan, untuk itu diharapkan pemerintah dapat lebih meningkatkan penerimaan pajak restoran.

3. Agar mekanisme pemungutan pajak dan pengawasan pemungutan pajak berjalan secara efektif, efesien dan menjadi lebih baik lagi maka perlu ditingkatkannya kinerja aparat pemungut dan pengawasan pemungutan pajak yang disiplin, sesuai dengan peraturanperaturan yang berlaku.

\section{DAFTAR PUSTAKA}

Adam Smith, (2015). An Inquiri into the Natural and causes of Wealth of Nations, Yogyakarta.

Adriani, (2016). Perpajakan, Edisi 2, Jakarta.

Alfan Lamia 2015. Analisis efektifitas dan kontribusi pemungutan pajak restoran, pajak reklame, dan pajak penerangan jalan pada pendapatan asli daerah kabupaten minahasa utara. Jurusan Akuntansi Universitas Sam Ratulangi Manado. Jurnal Berkala Ilmiah $\begin{array}{llllll}\text { Efisiensi } & \text { Vol } & 15, & \text { No. } & 5 & \text { Tahun }\end{array}$ https://ejournal.unsrat.ac.id/index.php/jbie/article/view/10474

Edward W. Memah 2013. Efektivitas dan kontribusi penerimaan pajak hotel dan restoran terhadap pad kota manado. Jurusan Akuntansi Universitas Sam Ratulangi Manado. Jurnal Riset Ekonomi, Manajemen, Bisnis dan Akuntansi Vol. 1 No. 3 Tahun 2013 Hal. 775-881. https://ejournal.unsrat.ac.id/index.php/emba/article/view/1896

Mardiasmo, (2016). Perpajakan, Edisi Revisi 2016, Yogyakarta.

Randy J.R. Walakandou 2013. Analisis kontribusi pajak hotel terhadap Pendapatan Asli Daerah (PAD) di kota manado. Jurusan Akuntansi Universitas Sam Ratulangi Manado. Vol $\quad$ 1, $\quad$ No $\quad 3 \quad$ (2013). https://ejournal.unsrat.ac.id/index.php/emba/article/view/1879

Seragih, (2016). Peningkatan PAD Sebenarnya Akses Dari Pertumbuhan Ekonomi, Salemba Empat, Jakarta.

Soemitro, (2015). Perpajakan, Edisi 1. Penerbit Salemba Empat, Jakarta.

Soeratmo dan Suparmo, (2015). Pajak Daerah dan Retribusi Daerah, Edisi 1. Penerbit

PT. Raja Grafindo Persada, Jakarta.

Supramono dan Theresia, (2015). Perpajakan Indonesia, Edisi 1. Penerbit Andi, Yogyakarta.

Waluyo, (2016). Perpajakan Indonesia, Edisi 6. Penerbit Salemba Empat, Jakarta. 